\title{
Platelet glycoprotein Ib $\alpha$ is an important mediator of ischemic stroke in mice
}

Simon F De Meyer ${ }^{1,2,3,4}$, Tobias Schwarz ${ }^{5}$, Daphne Schatzberg ${ }^{1,2}$ and Denisa D Wagner ${ }^{1,2,3^{*}}$

\begin{abstract}
Background: Platelets play an important role in ischemic stroke. GPIba is a major platelet receptor that is critical for platelet adhesion to exposed subendothelial matrix components at sites of vascular damage.

Methods: In this study, we used transgenic mice in which the extracellular part of GPIba is replaced by human interleukin 4-receptor (GPIba/IL4R $\alpha$ ). We observed normal brain vasculature in these mice. We compared infarct size in GPIba/IL4R $\alpha$ and wild-type (WT) mice 23 hours after 1-hour transient middle cerebral artery occlusion (tMCAO). In addition, the functional outcome was evaluated using a modified Bederson score.
\end{abstract}

Results: We found a significantly smaller infarct size in GPIba/IL4R $\alpha$ mice compared to WT mice $\left(38.0 \pm 6.5 \mathrm{~mm}^{3}\right.$ vs. $\left.74.2 \pm 8.6 \mathrm{~mm}^{3}, p<0.001\right)$. The decrease in infarct size was functionally relevant as indicated by a significantly better functional Bederson score in GPIba/IL4R $\alpha$ mice compared to WT animals (1.3 \pm 0.4 vs. $2.7 \pm 0.3, p<0.05)$.

Conclusions: Our data illustrate and further confirm the important role of platelet GPIb $\alpha$ in ischemic stroke, suggesting that targeted inhibition of this receptor may open new avenues in stroke treatment.

\section{Background}

Stroke is one of the leading causes of death worldwide with limited treatment options [1]. Platelets play a pivotal role in cerebral ischemia/reperfusion injury by adhering to the damaged vessel wall, leading to further platelet recruitment and thrombus formation. The glycoprotein (GP) Ib-IX-V complex is a crucial platelet receptor for initial tethering and adhesion at sites of vascular injury. This abundant complex on the platelet surface $(12,500$ copies per cell) consists of the leucine-rich repeat glycoproteins GPIb $\alpha$, GPIb $\beta$, GPIX and GPV in a 2:2:2:1 ratio [2]. The adhesive function of GPIb-IX-V is mainly attributed to the interaction of GPIb $\alpha$ with its major ligand von Willebrand factor (VWF), exposed upon vascular damage. The central role of the GPIb $\alpha$-VWF interaction in mediating initial platelet adhesion is illustrated by the bleeding disorders Bernard Soulier syndrome [3] and von Willebrand disease [4], caused by deficiency of GPIb-IX$\mathrm{V}$ or VWF respectively. Besides its interaction with VWF, GPIb $\alpha$ can also engage counter-receptors such as $\alpha \mathrm{M} \beta 2$ (Mac-1) on neutrophils and P-selectin on activated platelets or endothelial cells [2]. Other GPIbo ligands include

\footnotetext{
* Correspondence: Wagner@idi.harvard.edu

${ }^{1}$ Immune Disease Institute, (3 Blackfan Circle), Boston, (MA 02115), USA

Full list of author information is available at the end of the article
}

$\alpha$-thrombin, clotting factors XI and XII, thrombospondin-I and high molecular weight kininogen [2]. Not surprisingly, the importance of GPIb $\alpha$ far exceeds that of VWF in arterial thrombosis [5]. Thus, by binding a variety of ligands, GPIb $\alpha$ is a central receptor in different vascular processes of thrombosis and inflammation, all of which may contribute to the progression of ischemic stroke. Here, we studied stroke development in transgenic mice expressing GPIb $\alpha$ in which the extracellular domain was replaced by an isolated domain of the $\alpha$-subunit of the human IL-4 receptor [6]. We found that these mice had better stroke outcome, as evidenced by smaller infarct volumes and better functional scores.

\section{Methods}

\section{Animals}

GPIb $\alpha /$ IL4R $\alpha$ mice [6] and wild-type (WT) type mice (Jackson Laboratory, Bar Harbor, ME) were 8-10 weeks old males on C57BL/6J background. All experimental procedures were approved by the Animal Care and Use Committee of the Immune Disease Institute (Boston, USA).

\section{Assessment of the cerebral vasculature}

For assessment of the cerebral vasculature, animals were deeply anesthetized with isoflurane and transcardially 
perfused with phosphate buffered saline, followed by $5 \mathrm{ml}$ of black ink. Brains were carefully removed, fixed in 4\% PFA and the Circle of Willis and major arteries were examined under a dissecting microscope. The development of the posterior communicating arteries (PComAs) was examined and scored as described [7].

\section{Platelet counts}

To measure platelet counts, blood was collected on EDTA using coated capillaries via retro-orbital puncture. Platelet count in whole blood was determined using a Beckman Coulter AcT Diff 2 Hematology analyzer.

\section{Induction of cerebral ischemia}

Focal cerebral ischemia was induced by $60 \mathrm{~min}$ transient middle cerebral artery occlusion (tMCAO) as described [8-10]. Mice were anesthetized with $2 \%$ isoflurane/oxygen mixture. Following a midline skin incision in the neck, the proximal common carotid artery, and the external carotid artery were ligated, and a standardized silicon rubber-coated 6.0 nylon monofilament (6021; Doccol Corp., Redlands, CA) was inserted and advanced via the right internal carotid artery to occlude the origin of the right MCA. Operation time per animal did not exceed 15 minutes. The intraluminal suture was left in situ for 60 minutes. Then, animals were re-anesthetized, and the occluding monofilament was withdrawn to allow reperfusion.

Some animals were exclusively used for laser-Doppler flowmetry (Periflux 5000, Perimed, Kings Park, NY) to monitor regional cerebral blood flow (rCBF) in the MCA territory $(6 \mathrm{~mm}$ lateral and $2 \mathrm{~mm}$ posterior from bregma).

Mice were excluded from analysis when death occurred within $24 \mathrm{~h}$ after tMCAO or when subarachnoid hemorrhage was mascroscopically observed during brain harvesting. No difference in exclusion rates between the two groups was observed.

\section{Assessment of infarct volume}

Mice were sacrificed 24 hours after tMCAO. Brains were quickly removed and cut into 2-mm-thick coronal sections using a mouse brain slice matrix. The slices were stained with 2\% 2,3,5-triphenyl-tetrazolium chloride (TTC; SigmaAldrich, St. Louis, MO) in PBS to visualize the infarctions. Sections were photographed with a digital Nikon D70 camera and infarct areas (white) were measured by a blinded rater using Image J software (National Institutes of Health; http://rsbweb.nih.gov/ij).

\section{Assessment of functional outcome}

Neurological function was assessed, blinded for the mouse genotype, $24 \mathrm{~h}$ after $\mathrm{tMCAO}$, using the modified Bederson score [11]. This test determines global neurological function according to the following scoring system: 0 , no deficit; 1 , forelimb flexion; 2 , decreased resistance to lateral push; 3 , unidirectional circling; 4 , longitudinal spinning; 5 , no movement.

\section{Statistical analysis}

For statistical analysis the unpaired 2-tailed t-test was used (PrismGraph 4.0 software package, La Jolla, CA). The Mann-Whitney U-test was used for analyzing the Bederson score. P values less than 0.05 were considered statistically significant. Results are shown as mean \pm SD.

\section{Results}

GPIb $\alpha /$ IL4R $\alpha$ and WT animals have comparable cerebral vasculature and regional cerebral blood flow

Upon assessment of the cerebral vasculature in WT $(\mathrm{n}=$ $5)$ and GPIb $\alpha / \operatorname{IL} 4 \operatorname{R} \alpha(\mathrm{n}=3)$ mice, no major anatomic differences were observed which could influence stroke outcome (Figure 1A). The circle of Willis and the distribution of the MCA trunk and branch appeared to be anatomically identical between the genotypes. In addition, the score assessing formation of the posterior communicating arteries of both hemispheres, which can influence susceptibility to tMCAO, did not differ significantly $(1.8 \pm 0.4$ for WT versus $1.7 \pm 0.3$ for GPIba/ IL4R $\alpha$ mice, $\mathrm{p}=0.82$, Figure $1 \mathrm{~B}$ ).

To compare rCBF in the right MCA territory, laser doppler flowmetry in WT $(\mathrm{n}=5)$ and GPIb $\alpha / \operatorname{IL} 4 \mathrm{R} \alpha(\mathrm{n}=$ 3) was monitored at baseline levels, after insertion of the occluding filament (ischemia) and 15 minutes after removal of the filament (reperfusion). After advancing the filament, the decrease in $\mathrm{rCBF}$ was similar between WT and GPIb $\alpha /$ IL 4 R $\alpha$ animals, indicating comparable occlusion of the MCA origin $(7.8 \pm 4.8 \%$ of baseline level in WT mice versus $8.8 \pm 1.8 \%$ of baseline level in GPIb $\alpha$ / IL4R $\alpha$ mice, $\mathrm{p}=0.88$, Figure $1 \mathrm{C})$. Fifteen minutes after reperfusion, $\mathrm{rCBF}$ was reconstituted in all animals to > $70 \%$ of baseline levels and again did not significantly differ between WT and GPIb $\alpha /$ IL4R animals $(80.9 \pm 6.6 \%$ of baseline level in WT mice versus $77.4 \pm 3.4 \%$ of baseline level in GPIb $\alpha /$ IL4R $\alpha$ mice; $p=0.69$, Figure 1C). Platelet counts of GPIb $\alpha / \operatorname{IL} 4 \mathrm{R} \alpha$ mice $\left(664 \pm 31 \times 10^{3} / \mu \mathrm{l}\right.$, $\mathrm{n}=6)$ were slightly lower than in WT animals (822 \pm $\left.62 \times 10^{3} / \mu \mathrm{l}, \mathrm{n}=9\right)$ although this difference was not significant $(\mathrm{p}=0.071$, Figure 1D).

\section{GPIb $\alpha /$ IL4R $\alpha$ animals have a better outcome after tMCAO}

To investigate the role of GPIb $\alpha$-mediated interactions in ischemic stroke, infarct sizes of GPIb $\alpha / \operatorname{IL} 4 \mathrm{R} \alpha(\mathrm{n}=7)$ and WT mice $(\mathrm{n}=12)$ were compared after one hour tMCAO and 23 hours of reperfusion. Interestingly, we found that GPIb $\alpha /$ IL 4 R $\alpha$ mice had a $\sim 50 \%$ reduction in infarct size compared to WT animals $\left(38.0 \pm 6.5 \mathrm{~mm}^{3}\right.$ versus $74.2 \pm 8.6 \mathrm{~mm}^{3}, \mathrm{p}<0.05$, Figure $2 \mathrm{~A}$ ). The 
A

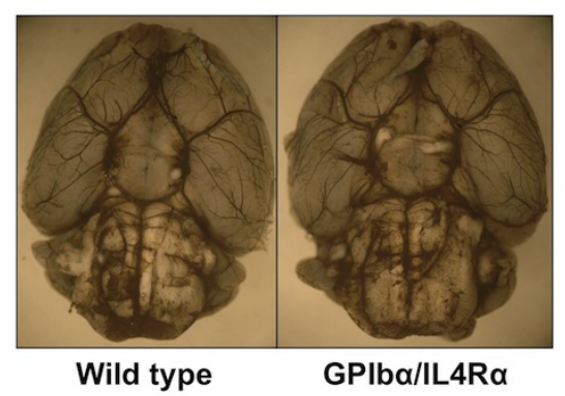

C

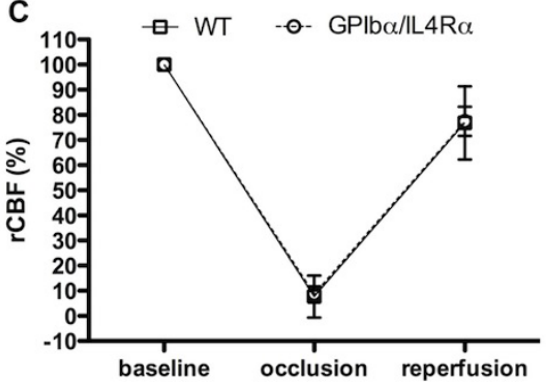

B

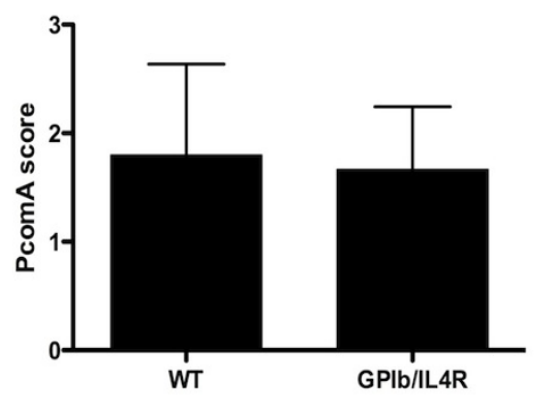

D

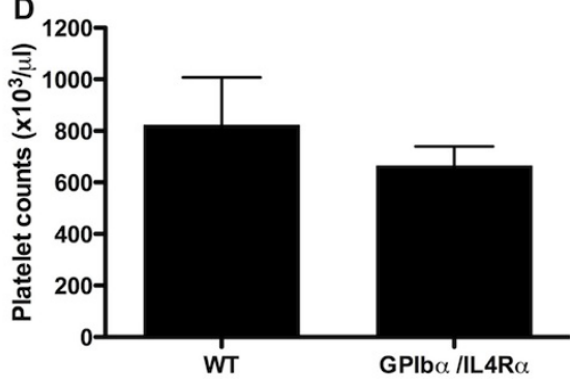

Figure 1 Regional cerebral blood flow and cerebral vasculature in WT and GPIb $\alpha /$ IL4R $\alpha$ mice. (A) Representative stainings of cerebral vasculature by black ink perfusion of WT and GPIba/LLRR mice. (B) Score assessing the posterior communicating arteries perfusion of WT ( $\mathrm{n}=$ 5) and GPIb $\alpha / I L 4 R \alpha$ mice $(n=3)$. (C) Regional cerebral blood flow of the right middle cerebral artery territory of $W T(n=5)$ and GPIb $/ / L 4 R \alpha$ mice $(n=3)$, measured at baseline, during occlusion and 15 min after reperfusion (reperfusion). (D) Platelet counts of WT $(n=9)$ and GPIba/ IL 4 R $\alpha$ mice $(n=6)$. No statistically significant differences were observed in all parameters (A-D).

decrease in infarct size was functionally relevant as shown by a significantly better outcome in the Bederson test for the GPIb $\alpha /$ IL4R $\alpha$ mice compared to WT mice $(1.3 \pm 0.4$ versus $2.7 \pm 0.3, \mathrm{p}<0.05$, Figure $2 \mathrm{~B})$. Taken together, these results indicate that the GPIb $\alpha$ receptor is critically involved in cerebral ischemia/reperfusion injury during stroke.

\section{Discussion}

We here report that mice lacking the extracellular part of GPIb $\alpha$ are protected from ischemic stroke as evidenced by $50 \%$ smaller infarct volumes and significantly better neurologic outcome when compared to WT mice. These results further establish the notion that GPIb $\alpha$ is critically involved in the pathogenesis of ischemic stroke
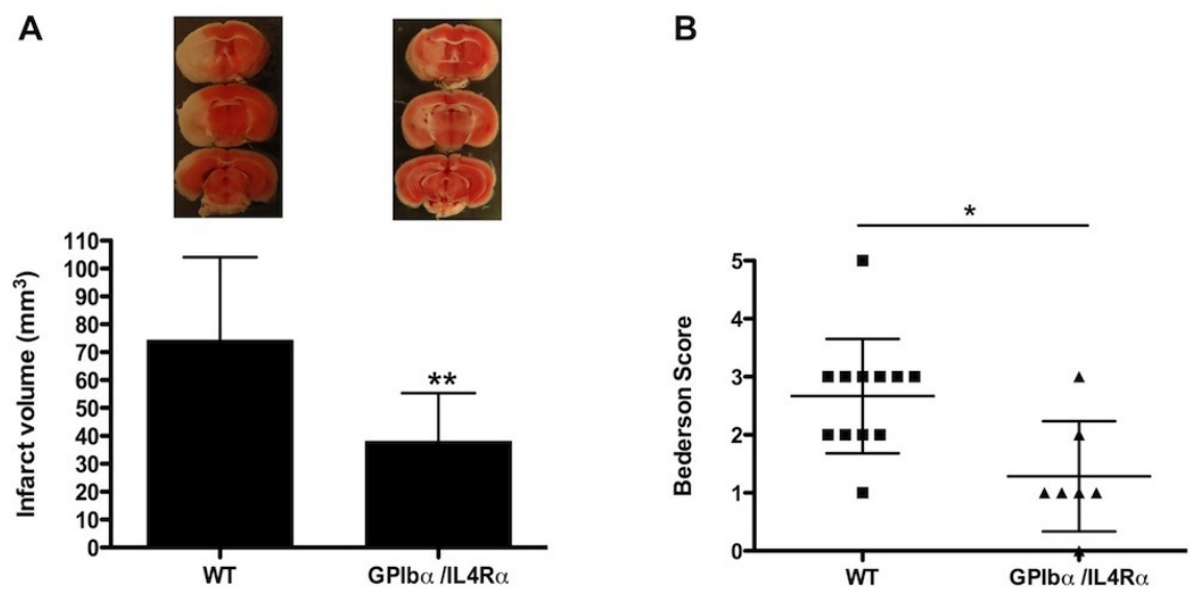

Figure 2 Infarct volumes and functional outcomes 23 hours after transient middle cerebral artery occlusion in WT and GPIb $\alpha /$ IL4R $\alpha$ mice. (A) Representative 2,3,5-TTC stains of 3 corresponding coronal brain sections of wild type (left) and GPIba/IL4R (right) mice $23 \mathrm{~h}$ after tMCAO (top) and brain infarct volumes of the 2 groups as measured by planimetry $23 \mathrm{~h}$ after tMCAO (bottom, $\mathrm{n}=12$ and 7 respectively). (B) Neurologic Bederson score of WT and GPIba/IL4R $\alpha$ mice as assessed at day 1 after tMCAO ( $n=12$ and 7 respectively) ${ }^{* *} p<.001,{ }^{*} p<.05$. 
$[12,13]$. Our findings are in agreement with an earlier study using the same mouse tMCAO model in which an anti-GPIb $\alpha$ monoclonal antibody was used to block the GPIb $\alpha$ receptor [14]. Use of this antibody led to a $60 \%$ reduction of infarct volumes compared to control mice, which was accompanied by a significant reduction in neurologic deficits [14]. We recently demonstrated that VWF deficient mice were protected from ischemic stroke $[8,15]$. Since VWF is the main ligand of GPIb $\alpha$ on platelets, our data support the notion of a pathophysiological role for the GPIb $\alpha$-VWF interaction in stroke, although we can not rule out that other GPIb $\alpha$ mediated interactions are also important and abrogated in GPIba/IL4R $\alpha$ mice. In full support of this, we showed that VWF-deficient mice that were reconstituted with a VWF mutant defective in binding to GPIb $\alpha$ retained their protection against stroke [9]. Moreover, several conditions, including the GPIb $\alpha$ Kozak polymorphism [16], GPIb $\alpha$ variants with increased binding to VWF [17] and high VWF levels [18,19], have all been reported to be associated with an increased risk of ischemic stroke in humans.

It has to be noted that GPIb $\alpha / \operatorname{IL} 4 \mathrm{R} \alpha$ mice were reported to have slightly reduced platelet counts [6]. Although not significant, also our measurements indicate a slightly lower platelet count in GPIb $\alpha /$ IL 4 R $\alpha$ mice compared to WT animals. Whereas we cannot completely exclude any effect of this small platelet count difference on stroke outcome, we believe that this is unlikely to cause the observed dramatic protection against stroke. Platelet adhesion to ferric chloride-treated mesenteric arterioles was virtually absent in GPIb $\alpha / \operatorname{IL} 4 \mathrm{R} \alpha$ mice, resulting in the complete abrogation of thrombus formation [5]. VWF-deficient mice are still able to form thrombi in this model, although thrombus formation is significantly delayed $[20,21]$. Although these studies showed that ligands other than VWF can support GPIb $\alpha$-dependent platelet adhesion, interfering with the binding of GPIb $\alpha$ to VWF has indeed been proven to have a profound antithrombotic effect [22-24]. Since an increasing amount of evidence suggests that GPIb $\alpha$ and VWF could also mediate inflammatory processes, further studies are needed to establish whether inhibition of these molecules also reduce inflammation in stroke [25].

The search for safe and efficient drugs for stroke management has been hampered by an unacceptable risk of fatal bleeding as seen e.g. with platelet aggregation inhibitors [26]. In this respect, it is encouraging that we did not observe intracranial hemorrhages after stroke in GPIba/ IL4R $\alpha$ mice. Also in VWF deficient mice, no increased bleeding was noticed in the tMCAO model $[8,9,15]$. In comparison with inhibition of platelet aggregation, neutralizing the VWF-GPIb $\alpha$-axis has been shown to have a better benefit-to-risk ratio with respect to bleeding in various models of experimental thrombosis [22-24]. Interestingly, a recent trial showed that administration of anti-VWF aptamer ARC1779, which blocks the VWFGPIb $\alpha$ interaction, reduced cerebral emboli signals in patients undergoing carotid endarterectomy [27].

\section{Conclusions}

In conclusion, using GPIb $\alpha /$ IL $4 R \alpha$ mice, we demonstrated the crucial role for GPIb $\alpha$ in ischemic stroke. Together with the already existing evidence, our results further warrant larger translational and clinical studies to assess the benefits or drawbacks of interfering with platelet adhesion in stroke.

\section{Acknowledgements}

SFDM is a postdoctoral fellow of the Flemish Fonds voor Wetenschappelijk Onderzoek (FWO), Belgium. This work was supported by National Heart, Lung, and Blood Institute of the National Institutes of Health grant R01 HL041002 (to D.D.W.).

\section{Author details}

${ }^{1}$ Immune Disease Institute, (3 Blackfan Circle), Boston, (MA 02115), USA. ${ }^{2}$ Program in Cellular and Molecular Medicine, Children's Hospital Boston, (300 Longwood Avenue), Boston, (MA 02115), USA. ${ }^{3}$ Department of Pediatrics, Harvard Medical School, (25 Shattuck Street), Boston, (MA 02115), USA. ${ }^{4}$ Laboratory for Thrombosis Research, KULeuven Campus Kortrijk, (E. Sabbelaan 53), Kortrijk, (B-8500), Belgium. ${ }^{5}$ Department of Neurology, University of Wuerzburg, (Josef-Schneider-Str. 11), Wuerzburg, (D-97080), Germany.

\section{Authors' contributions}

SFDM conceived the study, conducted experiments and wrote the paper DS conducted experiments and took care of mouse breeding. TS provided the tMCAO expertise. DW conceived and funded the study and revised the paper. All authors read and approved the final manuscript.

\section{Competing interests}

The authors declare that they have no competing interests.

Received: 1 July 2011 Accepted: 13 September 2011

Published: 13 September 2011

\section{References}

1. Lopez AD, Mathers CD, Ezzati M, Jamison DT, Murray CJ: Global and regional burden of disease and risk factors, 2001: systematic analysis of population health data. Lancet 2006, 367:1747-1757.

2. Andrews RK, Gardiner EE, Shen Y, Whisstock JC, Berndt MC: Glycoprotein Ib-IX-V. Int J Biochem Cell Biol 2003, 35:1170-1174.

3. Salles II, Feys HB, Iserbyt BF, De Meyer SF, Vanhoorelbeke K, Deckmyn H: Inherited traits affecting platelet function. Blood Rev 2008, 22:155-172.

4. De Meyer SF, Deckmyn H, Vanhoorelbeke K: von Willebrand factor to the rescue. Blood 2009, 113:5049-5057.

5. Bergmeier W, Piffath $\mathrm{CL}$, Goerge $T$, Cifuni $\mathrm{SM}$, Ruggeri ZM, Ware J, Wagner DD: The role of platelet adhesion receptor GPIbalpha far exceeds that of its main ligand, von Willebrand factor, in arterial thrombosis. Proc Natl Acad Sci USA 2006, 103:16900-16905.

6. Kanaji T, Russell S, Ware J: Amelioration of the macrothrombocytopenia associated with the murine Bernard-Soulier syndrome. Blood 2002, 100:2102-2107.

7. Murakami K, Kondo T, Epstein CJ, Chan PH: Overexpression of CuZnsuperoxide dismutase reduces hippocampal injury after global ischemia in transgenic mice. Stroke 1997, 28:1797-1804.

8. Kleinschnitz C, De Meyer SF, Schwarz T, Austinat M, Vanhoorelbeke K, Nieswandt B, Deckmyn H, Stoll G: Deficiency of von Willebrand factor protects mice from ischemic stroke. Blood 2009, 113:3600-3603. 
9. De Meyer SF, Schwarz T, Deckmyn H, Denis CV, Nieswandt B, Stoll G, Vanhoorelbeke K, Kleinschnitz C: Binding of von Willebrand Factor to Collagen and Glycoprotein Ibalpha, But Not to Glycoprotein Ilb/Illa, Contributes to Ischemic Stroke in Mice. Arterioscler Thromb Vasc Biol 2010, 30:1949-1951.

10. Clark WM, Lessov NS, Dixon MP, Eckenstein F: Monofilament intraluminal middle cerebral artery occlusion in the mouse. Neurol Res 1997, 19:641-648.

11. Bederson JB, Pitts LH, Tsuji M, Nishimura MC, Davis RL, Bartkowski H: Rat middle cerebral artery occlusion: evaluation of the model and development of a neurologic examination. Stroke 1986, 17:472-476.

12. Stoll G, Kleinschnitz C, Nieswandt B: Molecular mechanisms of thrombus formation in ischemic stroke: novel insights and targets for treatment. Blood 2008, 112:3555-3562.

13. Stoll G, Kleinschnitz C, Nieswandt B: The role of glycoprotein Ibalpha and von Willebrand factor interaction in stroke development. Hämostaseologie 2010, 30:136-138.

14. Kleinschnitz C, Pozgajova M, Pham M, Bendszus M, Nieswandt B, Stoll G: Targeting platelets in acute experimental stroke: impact of glycoprotein $\mathrm{Ib}, \mathrm{Vl}$, and Ilb/llla blockade on infarct size, functional outcome, and intracranial bleeding. Circulation 2007, 115:2323-2330.

15. Zhao B-Q, Chauhan AK, Canault M, Patten IS, Yang JJ, Dockal M, Scheiflinger F, Wagner DD: von Willebrand factor-cleaving protease ADAMTS13 reduces ischemic brain injury in experimental stroke. Blood 2009, 114:3329-3334.

16. Baker RI, Eikelboom J, Lofthouse E, Staples N, Afshar-Kharghan V, López JA, Shen Y, Berndt MC, Hankey G: Platelet glycoprotein Ibalpha Kozak polymorphism is associated with an increased risk of ischemic stroke. Blood 2001, 98:36-40.

17. Reiner AP, Kumar PN, Schwartz SM, Longstreth WT, Pearce RM, Rosendaal FR, Psaty BM, Siscovick DS: Genetic variants of platelet glycoprotein receptors and risk of stroke in young women. Stroke 2000, 31:1628-1633.

18. Bongers TN, de Maat MPM, van Goor M-LPJ, Bhagwanbali V, van Vliet HHDM, Gómez García EB, Dippel DWJ, Leebeek FWG: High von Willebrand factor levels increase the risk of first ischemic stroke: influence of ADAMTS13, inflammation, and genetic variability. Stroke 2006, 37:2672-2677.

19. Wieberdink RG, van Schie MC, Koudstaal PJ, Hofman A, Witteman JCM, de Maat MPM, Leebeek FWG, Breteler MMB: High von Willebrand Factor Levels Increase the Risk of Stroke. The Rotterdam Study. Stroke 2010, 41:2151-2156.

20. De Meyer SF, Vandeputte N, Pareyn I, Petrus I, Lenting PJ, Chuah MKL, VandenDriessche T, Deckmyn H, Vanhoorelbeke K: Restoration of plasma von Willebrand factor deficiency is sufficient to correct thrombus formation after gene therapy for severe von Willebrand disease. Arterioscler Thromb Vasc Biol 2008, 28:1621-1626.

21. Denis C, Methia N, Frenette PS, Rayburn H, Ullman-Culleré M, Hynes RO, Wagner DD: A mouse model of severe von Willebrand disease: defects in hemostasis and thrombosis. Proc Nat Acad Sci USA 1998, 95:9524-9529.

22. De Meyer SF, De Maeyer B, Deckmyn H, Vanhoorelbeke K: Von Willebrand factor: drug and drug target. Cardiovasc Hematol Disord Drug Targets 2009, 9:9-20.

23. De Meyer SF, Vanhoorelbeke K, Ulrichts H, Staelens S, Feys HB, Salles I, Fontayne A, Deckmyn H: Development of monoclonal antibodies that inhibit platelet adhesion or aggregation as potential anti-thrombotic drugs. Cardiovasc Hematol Disord Drug Targets 2006, 6:191-207.

24. Vanhoorelbeke $K$, Ulrichts $H$, Van de Walle G, Fontayne A, Deckmyn H: Inhibition of platelet glycoprotein $\mathrm{lb}$ and its antithrombotic potential. Curr Pharm Des 2007, 13:2684-2697.

25. Stoll G, Kleinschnitz C, Nieswandt B: Combating innate inflammation: a new paradigm for acute treatment of stroke? Ann N Y Acad Sci 2010, 1207:149-154.

26. Hankey GJ, Eikelboom JW: Antithrombotic drugs for patients with ischaemic stroke and transient ischaemic attack to prevent recurrent major vascular events. Lancet Neurol 2010, 9:273-284.

27. Markus HS, McCollum C, Imray C, Goulder MA, Gilbert J, King A: The von Willebrand Inhibitor ARC1779 Reduces Cerebral Embolization After Carotid Endarterectomy: A Randomized Trial. Stroke 2011, 42:2149-2153. doi:10.1186/2040-7378-3-9

Cite this article as: De Meyer et al:: Platelet glycoprotein Ib $\alpha$ is an important mediator of ischemic stroke in mice. Experimental \& Translational Stroke Medicine 2011 3:9.

\section{Submit your next manuscript to BioMed Central and take full advantage of:}

- Convenient online submission

- Thorough peer review

- No space constraints or color figure charges

- Immediate publication on acceptance

- Inclusion in PubMed, CAS, Scopus and Google Scholar

- Research which is freely available for redistribution

Submit your manuscript at www.biomedcentral.com/submit
C Biomed Central 